\title{
ANALISIS DETEKSI LABA OVERSTATED UNTUK MENGANALISIS LAPORAN KEUANGAN PT. UNILEVER INDONESIA TBK PERIODE 2016 - 2019
}

\author{
Amelia Ramadani ${ }^{1}$, Fezi Waldeseska Aulia ${ }^{2 *}$, Nurul Hikmah Putri ${ }^{3}$ \\ Program Studi Akuntansi, Fakultas Ekonomi dan Bisnis,Universitas \\ Muhammadiyah Riau \\ feziwaldeseska133@gmail.com,
}

\begin{abstract}
The purpose of this study is to detect overstated earnings to analyze the financial statements of PT. Unilever Indonesia Tbk. Financial statements are the result of management's accountability for the use of the resources entrusted to them. Financial statement data are researched and explored to find the potential for overstated earnings using the indicators proposed by Tan \& Robinson (2014). The results show that (1) an indication of aggressive revenue recognition at PT. Unilever was not found and operating cash flow was normal. (2) In the context of the suspension of expenses on PT. Unilever, there is no amortization period which is longer than similar companies, and there are no deferred costs other than taxes in the financial position as assets. (3) For non-operating income classification items, the description of PT. Unilever's operations is as appropriate, there are no recurring items included in revenue. (4) Operational Cost Classification for operational costs of PT. Unliver has no extraordinary fees or margins, everything is presented fairly.
\end{abstract}

Keyword: Overstated earnings, Aggressive revenue recognition, Operating expenses

\begin{abstract}
Abstrak : Tujuan penelitian ini mendeteksi potensi laba overstated untuk menganalisis laporan keuangan PT. Unilever Indonesia Tbk. Laporan keuangan merupakan hasil pertanggung jawaban manajemen atas penggunaan sumber daya yang dipercayakan kepada mereka. Data laporan keuangan diteliti dan dieksplorasi untuk mencari potensi laba overstated menggunakan indikator yang dikemukakan Tan \& Robinson (2014). Hasil menunjukkan bahwa (1) Indikasi pengakuan pendapatan yang agresif pada PT. Unilever tidak ditemukan dan arus kas operasi berjalan dengan wajar. (2) Dalam konteks penangguhan beban pada PT. Unilever, tidak terdapat amortisasi yang periodenya lebih lama dibandingkan dengan perusahaan sejenis, dan tidak terdapat biaya tangguhan selain pajak di posisi keuangan sebagai aset. (3) Untuk item klasifikasi non-operasi pendapatan, deskripsi operasi PT. Unilever sesuai dengan hal yang semestinya, tidak terdapat item berulang yang termasuk dalam pendapatan. (4) dalam hal kandungan klasifikasi biaya operasional untuk biaya operasional PT. Unliver tidak terdapat biaya maupun margin yang luar biasa, semua tersaji secara wajar.
\end{abstract}

Kata Kunci : Laba overstated, Pengakuan pendapatan agresif, Beban operasi

\section{A. PENDAHULUAN}

Laporan keuangan merupakan salah satu sumber informasi yang menggambarkan kondisi perusahaan secara finansial pada suatu periode. Laporan keuangan menunjukkan hasil pertanggungjawaban manajemen atas penggunaan sumber daya yang dipercayakan kepada mereka. Bagi perusahaan yang telah go public laporan keuangan tersebut dipublikasikan kepada pihak eksternal, tujuannya yaitu untuk memberi informasi terkait posisi keuangan, kinerja keuangan, dan arus kas pada pengguna laporan keuangan dalam pembuatan keputusan ekonomik (PSAK No.1 2017 paragaraf 09). Kasus skandal akuntansi pernah dialami oleh perusahaan elektronik terkemuka di dunia Toshiba dengan modus membukukan laba operasi secara overstated yaitu sebesar setara 
1,2 Milyar USD tahun 2008-2014 namun auditor gagal menemukan ketidakwajaran tersebut (reuters.com).

Kasus serupa juga pernah terjadi di Indonesia pada tahun 2001 yang menimpa PT Kimia Farma Tbk. manajer Kimia Farma membukukan laba bersih sebesar Rp 132 milyar (bisnis.tempo.co; Oscar \& Harindahyani, 2019). Kemudian dilakukan audit ulang pada 3 Oktober 2002 atas laporan keuangan tahun 2001 lalu disajikan ulang (restated). Hasilnya laba hanya sebesar Rp 99,56 milyar. Hal ini disebabkan karena terdapat overstated pada beberapa unit perusahaan. Pada 2017, kasus skandal akuntansi yang menerpa lini usaha perusahaan multinasional British Telecom di Italia. Modus skandal ini yaitu membesarkan penghasilan lewat perpanjangan kontrak palsu dan invoice-nya serta transaksi fiktif dengan vendor. Praktik ini telah terjadi sejak 2013 lalu dengan maksud mendapatkan bonus (tantiem) (warta ekonomi.co.id, 2017.) Praktik tersebut gagal dideteksi oleh Price Waterhouse Coopers $(\mathrm{PwC})$ selaku kantor akuntan publik terkemuka dan termasuk Big Four. Akibatnya, reputasi kantor akuntan publik tercemar dan mencoreng profesi akuntan publik.

Pada dasarnya laporan keuangan adalah alat komunikasi antar badan usaha dan pembaca laporan keuangan yang berisi informasi mengenai posisi keuangan, kinerja, maupun arus dana suatu badan usaha dalam suatu periode. Laporan keuangan seharusnya disusun sesuai dengan standar akuntansi yang berlaku umum di Indonesia agar tidak menyesatkan para pemakai laporan keuangan dalam mengambil keputusan ekonomi.

Semua orang dapat melakukan suatu kesalahan, termasuk seorang akuntan. Karena akun-akun akuntansi saling terkait, kesalahan dalam catatan keuangan sangat mempengaruhi kegiatan operasional perusahaan. Misalnya Entri pendapatan yang tidak perlu akan melebih-lebihkan (overstated) pendapatan bersih dan laba ditahan, sementara entri biaya yang tidak perlu, bisa mengecilkan (understated) pendapatan bersih dan laba ditahan. Namun akuntan dapat memposting entri jurnal untuk memperbaiki kesalahan dalam laporan keuangan tersebut.

Jika terjadi kesalahan pada akun beban aturan umumnya adalah, overstated akun beban akan menyebabkan understated nya pendapatan bersih dan sebaliknya understated beban akan menyebabkan overstated nya pendapatan. Agar lebih kompleks, beban seringkali berupa accrued expense maupun deferred expense. Jika beban di accrue ketika tidak perlu, maka akan meyebabkan understated nya pendapatan. Misalnya, jika akuntan accrued beban bunga pada akhir tahun dan ternyata beban bunga tidak perlu dibayar, pendapatan bersih akan understated. Demikian juga, biaya yang ditangguhkan atau deferred yang tidak perlu akan menyebabkan overstates pendapatan bersih.

Jika terjadi kesalahan pada pendapatan. Apabila pendapatan kotor overstated, maka pendapatan bersih akan overstated juga demikian sebaliknya. Namun, akuntan harus tetap melihat secara teliti untuk melihat kesalahan mengenai pendapatan ditangguhkan(deferred) dan yang masih harus dibayar (accrued). Pendapatan ditangguhkan terjadi ketika sebuah perusahaan menerima uang tunai untuk produk atau layanan yang mereka belum lakukan atau kirim. Jika akuntan mendeferred pendapatan yang tidak perlu, pendapatan bersih pasti understated. Accrued pendapatan berarti perusahaan telah mengakui pendapatan tetapi belum menerima uang tunai. Jika accrued pendapatan yang tidak perlu dicatat, pendapatan bersih akan overstated.

Apabila terdapat kesalahan di persediaan. Kesalahan sekitar saldo persediaan mempengaruhi akun Harga Pokok Penjualan (HPP) dan pendapatan bersih. Akuntan menghitung HPP dengan menambahkan pembelian persediaan pada saldo awal dan mengurangkan total saldonya dengan persediaan akhir. Jika nilai akhir persediaan overstated (berlebihan), itu berarti HPP understated dan laba bersihnya overstated. Efek sebaliknya terjadi kesalahan dalam saldo awal persediaan; overstated persediaan awal berarti HPP menjadi overstated dan laba bersih understated.

Dan apabila terjadi kesalahan pada efek ekuitas, kesalahan laporan laba rugi tidak selalu mempengaruhi aset dan kewajiban, tetapi mereka mempengaruhi ekuitas. Pada akhir masa pembukuan, akuntan menutup pendapatan bersih ke laba ditahan. Saldo laba mewakili penghasilan dan 
akumulasi ekuitas perusahaan. Jika pendapatan bersih overstated untuk periode tertentu, saldo laba ditahan juga dipastikan akan overstated juga dan sebaliknya.

Tugas akuntan adalah memeriksa dan melaporkan segala sesuatu yang berkenaan dengan masalah keuangan dari emiten. Agar laporan keuangan disajikan secara wajar dan dapat diandalkan dalam pengambilan keputusan, laporan keuangan harus diperiksa diaudit oleh akuntan publik. Kecenderungan yang terjadi, pihak manajemen perusahaan berusaha menonjolkan informasi yang baik dengan tujuan meningkatkan nilai saham yang ditawar. Sementara stakeholders lainnya menginginkan nilai saham wajar sebagai cerminan keadaan perusahaan yang sesungguhnya.

Pentingnya peran akuntan dalam melakukan pemeriksaan laporan keuangan ini harus patuh pada kode etik profesi akuntan publik dan berpegang pada Standar Profesional Akuntan Publik agar dapat menghindari terjadinya penipuan dalam pemeriksaan, antara lain terjadinya "mark up" atau "overstated" menaikkan nilailaba perusahaan dari nilai yang sebenarnya. Berdasarkan hal diatas laporan keuangan yang overstated adalah penggelembungan laba keuntungan dalam laporan keuangan perusahaan.

Kondisi perusahaan yang tidak sehat seringkali oleh manajemen ditutupi dengan menampilkan atau melaporkan kinerja keuangannya tetap baik. Akibat dari kondisi seperti itulah manajemen biasanya berkolusi dengan akuntan agar kinerjanya tetap bisa dinilai baik oleh para calon investor, pemilik atau pihak lain yang berkepentingan dengan kinerja perusahaan yang baik. Berdasarkan uraian latar belakang diatas, maka peneliti tertarik untuk meneliti dengan judul "Deteksi Laba Overstated Untuk Menganalisis Laporan Keuangan PT. Unilver Indonesia Tbk Periode 2016 -2019”.

\section{B. KERANGKA TEORITIS}

\section{Teori Agensi}

Teori keagenan menyatakan bahwa perusahaan yang memisahkan fungsi pengelolaan dan kepemilikan akan rentan terhadap konflik keagenan (Jensen and Mackling, 1976). Pada model keagenan dirancang sebuah sistem yang melibatkan kedua belah pihak yaitu manajemen dan pemilik. Selanjutnya, manajemen dan pemilik melakukan kesepakatan (kontrak) kerja untuk mencapai manfaat (utilitas) yang diharapkan. Lambert (2001) menyatakan bahwa dalam kesepakatan tersebut diharapkan dapat memaksimumkan utilitas pemilik (principal), dan dapat memuaskan serta menjamin manajemen (agent) untuk menerima reward. Manfaat yang diterima oleh kedua belah pihak didasarkan pada kinerja perusahaan (Azmi \& Januryanti, 2021; Azmi et al., 2021; Sugianto et al., 2020) Pada umumnya, kinerja perusahaan diukur dari profitabilitas (Penman, 2003). Besarnya profitabilitas, selanjutnya diinformasikan oleh manajemen kepada pihak pemilik melalui penyajian laporan keuangan.

Sesuai dengan agency theory, motivasi manajemen akrual dapat dikelompokkan ke dalam dua kategori: opportunistic dan signaling (Beaver, 2002). Pada motivasi opportunistic, manajemen melalui kebijakan aggressive accounting menghasilkan angka laba lebih tinggi daripada laba yang sesungguhnya. Apabila laporan laba tidak dapat menggambarkan laba yang sesungguhnya, maka laporan laba mengarah pada overstate earnings. Laba yang mengarah pada overstate earnings mengakibatkan laba menjadi kabur (opaque). Motivasi opportunistic yang dilakukan oleh manajemen berhubungan dengan kompensasi berdasarkan kontrak yang disepakati dengan pihak pemilik.

Pada motivasi signaling, manajemen menyajikan informasi keuangan (khususnya laba) diharapkan dapat memberikan sinyal kemakmuran kepada para pemegang saham. Laporan laba yang dapat memberikan sinyal kemakmuran adalah laba yang relatif tumbuh dan stabil (sustainable). Penman dan Zhang (2002) menyatakan bahwa sustainable earnings adalah laba yang mempunyai kualitas tinggi dan sebagai indikator future earnings; dan selanjutnya disebut sebagai persistensi laba (Sloan, 1996; Dechow dan Dichev, 2002; Francis, LaFond, Olsson dan Schipper, 2004).

Berdasarkan PSAK No. 1 dan pernyataan Beaver (2002) dapat dinyatakan bahwa manajemen laba yang dilakukan oleh manajemen lebih banyak didasarkan pada manajemen akrual, dan lebih khusus 
lagi akrual diskresi. Kebijakan akrual diskresi yang dilakukan oleh manajemen membawa dua konsekuensi. Pertama, jika kebijakan tersebut membawa keinformasian laba, maka kebijakan tersebut akan meningkatkan kualitas laba, sehingga laba semakin persisten. Kedua, jika kebijakan tersebut tidak membawa keinformasian laba (uninformative earnings), maka kebijakan tersebut akan menurunkan kualitas laba, sehingga laba menjadi kabur (opaque).

Pada teori keagenan, manajemen menyajikan laporan keuangan dapat dimotivasi oleh dua motivasi: opportunistic dan signaling. Motivasi tersebut mendorong manajemen melakukan manajemen laba (earnings management). Pada motivasi opportunistic, manajemen cenderung manyajikan laba lebih tinggi daripada yang sesungguhnya, karena berhubungan dengan kompensasi. Sementara pada motivasi signaling, manajemen cenderung menyajikan laba yang mempunyai kualitas, karena berhubungan dengan evaluasi kinerja dan selanjutnya digunakan sebagai sinyal kepada para pemegang saham.

\section{Pengakuan Pendapatan Agresif}

Pengakuan pendapatan yang agresif adalah salah satu bentuk manajemen laba yang paling populer yang dikutip oleh SEC. Tanda-tanda peringatan termasuk pertumbuhan piutang melebihi pertumbuhan penjualan, dan peningkatan piutang harian. Pengakuan pendapatan agresif ini terjadi ketika perusahaan melebih-lebihkan pendapatan dan pendapatan dengan melaporkan pendapatan pada laporan laba rugi lebih awal dari ke ekonomian atau dalam beberapa kasus jika tidak ada transaksi yang sebenarnya. Umumnya, pendapatan diakui ketika perusahaan telah mengirimkan barang atau jasa kepada pelanggannya, yang biasa dilakukan sebelum atau sesudah uang tunai diterima. Akibatnya, terdapat perbedaan waktu antara waktu transaksi penjualan tercermin di laporan laba rugi dan laporan arus kas.

Perusahaan yang sangat agresif dalam melaporkan pendapatan dengan melaporkannya terlalu cepat atau secara curang pada laporan laba rugi, akan mengakibatkan salah saji yang sesuai di neraca. Jika laba dibesar-besarkan, laba ditahan dilebih-lebihkan pada neraca. Untuk mengkompensasinya, perusahaan harus melebih-lebihkan asset, mengecilkan kewajiban atau mengecilkan beberapa komponen ekuitas pemilik lainnya.Pengakuan pendapatan yang agresif dan curang mengakibatkan peningkatan piutang yang besar. Hal ini dapat diteksi dengan melihat kecepatan pertumbuhan piutang dari waktu ke waktu relatif terhadap pendapatan, memeriksa hari penjualan dalam rasio piutang atau membandingkan arus kas dari operasi relatif terhadap pendapatan untuk ketidaksesuaian antara pendapatan yang dilaporkan dank as yang diterima dari pelanggan.

\section{Penangguhan Beban}

Pengeluaran yang belum merupakan biaya dalam tahun buku yang sedang berjalan, tetapi masih tercatat sebagai harta (deferred charges). Beban ditangguhkan adalah biaya yang dibayar dimuka jangka panjang, tetapi aset dasarnya tidak akan sepenuhnya digunakan/dikonsumsi sampai satu atau beberapa periode masa depan telah selesai. Maka dari itu, beban yang ditangguhkan dilakukan di neraca sebagai aset sampai biaya tersebut digunakan. Setelah digunakan, biaya yang ditangguhkan akan diklasifikasi sebagai beban dalam periode berjalan. Biaya yang ditangguhkan seringkali berasal dari bisnis yang melakukan pembayaran untuk barang dan jasa yang belum diterimanya, seperti premi asuransi dibayar di muka atau sewa.

Untuk peenerimaan diskon, beberapa perusahaan membayar sewa dimuka. Pembayaran dimuka ini dicatat sebagai biaya yang ditangguhkan di neraca dan dianggap sebagai aset sampai dibebankan sepenuhnya. Setiap bulan, perusahaan mengakui sebagian dari sewa dibayar dimuka sebagai beban pada laporan keuangan. Setiap bulannya, entri lain dibuat untuk memindahkan uang tunai dari biaya yang ditangguhkan di neraca ke biaya sewa pada laporan laba rugi.

Biaya yang ditangguhkan adalah setara dengan biaya dibayar dimuka jangka panjang, yang merupakan pengeluaran yang dibayarkan untuk aset dasar yang akan dikonsumsi pada periode mendatang, biasanya beberapa bulan. Biaya dibayar di muka adalah rekening koran, sedangkan biaya ditangguhkan adalah rekening tidak lancar. 
4. Klasifikasi Non-Operasi Pendapatan

Banyak analisis fokus pada bisnis inti perusahaan melalui pendapatan operasional merupakan hal yang umum. Meski sangat baik untuk memahami beberapa banyak keuntungan perusahaan yang berasal dari operasi normal yang berulang, kita harus memahami bahwa perusahaan menyadari hal ini. Salah satu taktik umum dari manajer yang tidak bermoral adalah dengan tidak tepat melaporkan keuntungan non operasional sebagai bagian dari pendapatan operasi. Jenis pendapatan non operasi dapat dibedakan menjadi dua jenis, yaitu :

- Pendapatan yang diperoleh dari penggunaan aktiva atau sumber ekonomi perusahaan oleh pihak lain. Seperti pendapatan bunga,sewa dan royalti.

- Pendapatan yang diperoleh dari penjualan aktiva diluar barang dagangan atau hasil produksi. Seperti penjualan surat-surat berharga dan penjualan aktiva tak berwujud.

5. Klasifikasi Biaya Operasional

Menurunkan biaya ke dalam laporan laba rugi dan mengklasifikasinya sebagai kerugian khusus atau luar biasa agar laba operasi normal terlihat lebih besar. Biayaoperasional diperlukan untuk membuat barang modal menjadi berfungsi untuk melakukan kegiatan proses produkasi.

\section{METODE PENELITIAN}

1. Jenis dan Model Penelitian

Jenis penelitian ini merupakan penelitian kualitatif yang bersifat deskriptif. Metode yang digunakan didalam penelitian ini adalah content analysis atau analisis isi. Isi yang digunakan dalam penelitian ini untuk memahami isi dari suatu dokumen (Azmi et al., 2019).

2. Data dan Sumber Data

Data yang digunakan adalah data sekunder yang diperoleh dari materi mata kuliah Analisa Laporan Keuangan.

3. Teknik Pengumpulan Data

Teknik pengumpulan data yang digunakan dalam pengumpulan data penelitian ini adalah teknik simak dan catat.

\section{Validitas Data}

Validitas data yang digunakan pada penelitian ini merupakan menggunakan triangulasi data yaitu dengan cara memeriksa kebenaran data dengan menggunakan perbandingan antara data dari sumber data yang satu dengan sumber data yang lain, sehingga keaslian dan kebenaran data akan diuji oleh sumber data yang berbeda.

5. Teknik Analisis Data

Teknik analisis data yang digunakan didalam penelitian ini adalah content analysis (kajian isi). Analisis isi merupakan alat penelitian yang digunakan untuk menentukan keberadaan kata, tema atau konsep tertentu didalam beberapa data kualitatif tertentu (yaitu teks), dengan menggunakan analisis isi, penelitian dapat mengukur dan menganalisis keadaan dan kebenaran dari suatu konsep tertentu.

\section{HASIL DAN PEMBAHASAN}

Manajemen laba yaitu kebijakan yang sering dilakukan perusahaan dengan tujuan memanipulasi laba dari hasil operasinya. Manajemen laba ini bisa dilakukan dengan cara memilih metode- metode akuntansi yang bisa menaikkan laba (overstated) atau menurunkan laba (understated). Arens (2008:430-432) menjelaskan bahwa kecurangan merupakan segala upaya penipuan yang sengaja, yang bertujuan mengambil harta atau hak orang atau pihak lain. Dua jenis kecurangan akuntansi yang utama adalah:

1. Pelaporan keuangan yang curang

Pelaporan keuangan yang curang berupa salah saji atau pengabaian jumlah atau pengungkapan yang disengaja dilakukan untuk menipu para pemakai laporan keuangan tersebut. Sebagian besar kasus melibatkan salah saji jumlah yang disengaja, bukan pengungkapan. Pengabaian jumlah kurang lazim dilakukan, tetapi perusahaan dapat saja melebihsajikan laba dengan mengabaikan utang usaha dan kewajiban lainnya. 
Kebanyakan kasus pelaporan keuangan yang curang yaitu melibatkan upaya melebihsajikan laba baik dengan melebihsajikan aktiva dan laba atau dengan mengabaikan kewajiban dan beban,perusahaan juga sengaja merendahsajikan laba. Hal ini bisa saja dilakukan dalam upaya mengurangi pajak penghasilan. Perusahaan juga mungkin sengaja merendahsajikan laba ketika laba itu tinggi. untuk membentuk cadangan laba atau "cookie jar reserve", yang dapat digunakan untuk memperbesar laba dalam periodik mendatang, praktik ini disebut income smoothing (perataan laba) dan earnings management (pengaturan laba).

Pengaturan laba (earnings management) terkait tindakan manajemen yang disengaja untuk memenuhi tujuan laba, sedangkan perataan laba (income smoothing) yaitu salah satu bentuk pengaturan laba di mana pendapatan dan beban ditukar-tukar di antara periodik-periodik untuk mengurangi fluktuasi laba. Salah satu teknik untuk meratakan laba yaitu dengan mengurangi nilai persediaan dan aktiva lain perusahaan yang diperoleh pada saat akuisisi, yang menghasilkan laba yang lebih tinggi ketika aktiva tersebut nanti dijual. Penyebab menaikkan laba adalah karena kepercayaan yang sangat tinggi mengenai harapan masa depan dan juga karena adanya unsur kesengajaan memberi kesan baik kepada pihak lain terutama untuk menarik investor. Hal tersebut menjadikan informasi keuangan tidak benar, keakuratan ini dapat berupa mark up overstated.

\section{Penyalahgunaan aktiva}

Penyalahgunaan (misappropriation) aktiva adalah kecurangan yang melibatkan pencurian aktiva entitas. Dalam banyak kasus, tetapi tidak semata, jumlah yang terlibat tidak material terhadap laporan keuangan. Akan tetapi, pencurian aktiva perusahaan seringkali mengkhawatirkan manajemen,tanpa memperhatikan materialitas jumlah yang terkait, karena pencurian bernilai kecil menggunung seiring dengan berjalannya waktu. Berikut beberapa pertanyaan mengenai Ceklist Warning yang perlu diperhatikan dalam mendeteksi laba overstated (Tan \& Robinson, 2014) :

\section{Pengakuan Pendapatan Agresif}

1. Periksa kebijakan pengakuan pendapatan dalam catatan kaki terhadap perusahaan sejenis.

Kebijakan pendapatan dilakukan dengan mencatat dan mencantumkan sesuai dengan nilai yang seharusnya.Bila pendapatan yang diakui tidak sama dengan yang seharusnya (terlalu besar atau terlalu kecil), maka informasi yang disajikan dalam laporan laba rugi menjadi tidak wajar. Pengakuan kebijakan pendapatan adalah suatu yang penting untuk menentukan kapan suatu penghasilan diakui sebagai pendapatan. Analisis akuntansi pendapatan merupakan suatu analisis yang dilakukan terhadap pengakuan, kebijakan, pengukuran, dan penyajian pendapatan dan beban pada sebuah perusahaan. Pendapatan sangat penting untuk mendapatkan yang wajar.

PT. Unilever mengakui pendapatan ketika pelanggan memperoleh kendali atas barang yang diperoleh.

2. Apakah Piutang pelanggan tumbuh lebih cepat dari pada pendapatan?

Piutang merupakan jumlah pendapatan penjualan tidak tertagih pada akhir periode akuntansi. Pendapatan adalah penghasilan yang timbul karena pelaksanaan aktivitas perusahaan.

Berdasarkan indeks trend dan berseri peningkatan penjualan bersih PT. Unilever tahun 2016-2019 hanya sebesar 7\% sementara piutang dagang perusahaan tumbuh sebesar $44 \%$

3. Apakah arus kas operasi secara signifikan lebih rendah daripada laba akuntansi? Selain laba, arus kas operasi juga menunjukan daya prediksi yang baik terhadap arus kas operasi masa depan. Pada PT. Unilever arus kas operasi lebih tinggi daripada laba akuntansi

4. Apakah pendapatan yang signifikan terjadi diakhir tahun?

Berdasarkan laporan kuartal dari tahun 2016 - 2019 nilai penjualan bersih tidak naik signifikan diakhir tahun

\section{Penangguhan Beban}

1. Apakah periode depresiasi / amortisasi lebih lama dari perusahaan sejenis? 
Perhitungan depresiasi dan mortisasi bertujuan untuk menghitung biaya penyusutan aset, juga bertujuan untuk menghitung masa pakai asetnya. Menghitung depresiasi dan amortisasi bisa membantu perusahaan menentukan waktu mengganti aset dan memaksimalkan masa pakai aset tersebut. Pada laporan tahunan PT. Unilever bila dibandingan dengan perusahaan sejenis (Mayora) periode nya tidak lebih lama.

2. Apakah ada biaya tangguhan yang dicatat sebagai asset di neraca (selain pajak)? Biaya ditangguhkan merupakan biaya yang dibayar dimuka jangka panjang, tetapi aset dasarnya tidak akan sepenuhnya digunakan sampai satu atau beberapa periode yang akan datang. Biaya yang ditangguhkan dilakukan di neraca sebagai aset sampai biaya tersebut digunakan. Setelah digunakan, biaya yang ditangguhkan akan diklasifikasi sebagai beban dalam periode berjalan. Pada PT. Unilever hanya terdapat liabilitas pajak tangguhan dan tidak terdapat asset di neraca selain pajak.

3. Apakah ada asset yang tidak biasa atau peningkatan besar yang tidak dijelaskan dalam aset seperti inventaris, terutama yang terkait dengan pendapatan?

Peningkatan aset masa lalu akan menggambarkan profitabilitasyang akan datang dan pertumbuhan yang akan datang. Pada PT. Unilever aset perusahaan tercatat wajar baik, peningkatan maupun penurunann nya.

\section{Klasifikasi Non-Operasi Pendapatan}

1. Apakah "keuntungan" termasuk dalam pendapatan?

Pendapatan merupakan suatu penghasilan yang diperoleh dari penjualan barang atau jasa selama suatu periode tertentu, sedangkan keuntungan merupakan suatu penghasilan yang jumlahnya lebih dari modal yang dikeluarkan. Keuntungan tidak termasuk kedalam pendapatan begitu yang terjadi pada PT. Unilever.

2. Apakah deskripsi operasi perusahaan sesuai?

Deskripsi operasi perusahaan adalah kegiatan-kegiatan yang dilaksanakan perusahaan untuk tercapainya rencana - rencana untuk tercapainya tujuan perusahaan. Deskripsi perusahaan PT. Unilever sesuai dengan operasi yang telah dihitung.

3. Apakah item satu kali atau tidak berulang termasuk dalam pendapatan?

Item satu kali atau tidak berulang mengacu pada entri yang jarang atau tidak biasa yang muncul di laporan keuangan perusahaan. Pada PT. Unilever tidak termasuk dalam pendapatan karena perusahaan hanya mengakui pendapatan (penjualan bersih) dagang.

4. Apakah ada keuntungan atau pendapatan berdasarkan revaluasi aset?

Revaluasi aset dapat digunakan pada perusahaan yang melakukan merger.

Pada PT. Unilever perusahaan tidak melakukan revaluasi aset.

\section{Klasifikasi Biaya Operasional}

1. Apakah ada biaya atau kerugian yang terdaftar sebagai ""khusus "eee, luar biasa, atau tidak berulang dibagian laporan laba rugi?

Biaya luar biasa merupakan kerugian dalam laporan keuangan perusahaan yang jarang terjadi dan tidak biasa. Pada dasarnya, biaya dianggap luar biasa karena bukan bagian dari operasional perusahaan. Laporan keuangan PT. Unilever tahun 2016 - 2019 memiliki pos - pos yang sama.

2. Apakah ada margin yang luar biasa tinggi dibandingkan dengan perusahaan sejenis (juga berlaku untuk penangguhan biaya)?

Margin merupakan selisih antara keuntungan dengan omset dalam sebuah bisnis dalam bentuk persentase. Pada PT. Unilever penurunan margin /beban perusahaan wajar sehingga tidak terdapat margin yang luar biasa tinggi.

\section{E. KESIMPULAN}

Berdasarkan keterangan pada pembahasan diatas, disimpulkan bahwa tidak terdapat indikasi pengakuan pendapatan agresif sepanjang tahun amatan dan arus kas operasi dinilai berjalan 
dengan wajar. Dalam hal apakah ada penagguhan beban yang berpotensi mengakibatkan laba overstated tidak ditemukan. Pada PT. Unilever tidak terdapat amortisasi yang periodenya lebih lama dibandingkan dengan perusahaan sejenis, dan tidak terdapat biaya tangguhan selain pajak dineraca sebagai aset.

Pada klasifikasi non-operasi pendapatan tidak juga ditemukan item berulang yang tidak termasuk klasifikasi non operasi jika dianalisa dari laporan keuangannya. Untuk klasifikasi biaya operasional pun tidak ditemukan biaya maupun margin yang luar biasa, berdasarkan penelaahan kami, seluruhnya tampak wajar. Dengan demikian untuk kasus PT Unilever tidak terdeteksi informasi mengenai adanya indikasi potensi laba overstated.

\section{DAFTAR PUSTAKA}

Annual Report PT Uniler Indonesia Tbk tahun 2016-2019

Arens, Alvin A., dkk. 2008. Auditing dan Jasa Assurance Pendekatan Terintegrasi. Edisi 12. Jakarta: Erlangga.

Azmi, Zul;, \& Januryanti. (2021). Faktor-Faktor yang Mempengaruhi Sticky Cost. 6(April), 274 280. https://doi.org/10.33087/jmas.v6i1.219

Azmi, Zul, Nasution, A., Wardayani, W., Muda, I., Supriyanto, S., Rizal, S., \& Hidayat, R. (2019). Grounded Theory in Accounting Research. ICASI 2019: Proceedings of The 2nd International Conference On Advance And Scientific Innovation, May 2020. https://doi.org/10.4108/eai.18-7-2019.2288566

Azmi, Zul, Nisa, O. H., \& Suci, R. G. (2021). Faktor yang mempengaruhi kecenderungan kecurangan akuntansi pada Rumah Sakit Kota Pekanbaru. Bilancia: Jurnal Ilmiah Akuntansi, $5(1), 1-14$.

Dwisanti, Ni Made. 2004. "Pengaruh Likuiditas, Solvabilitas dan Ukuran Perusahaan (Firm Size) terhadap Rentabilitas LPD di Kecamatan Ubud Kabupaten Gianyar". Skripsi Sarjana Jurusan Akuntansi, Fakultas Ekonomi Universitas Udayana.

Harahap, Sofyan Syafri. 2001. Analisis Kritis atas Laporan Keuangan. Cetakan Ketiga, PT. Raja Grafindo Persada: Jakarta.

Ikatan Akuntansi Indonesia. 2002. Standar Akuntansi Keuangan. Jakarta : Salemba Empat.

Oscar, J., \& Harindahyani, S. (2019). Pengaruh fee audit dan ukuran KAP terhadap manajemen laba pada perusahaan manufaktur yang terdaftar di bursa efek Indonesia (BEI) tahun 2014-2016. Calyptra: Jurnal Ilmiah Mahasiswa Universitas Surabaya, 8(1), 72-90.

Setiati, Fita dan Kusuma, Indra Wijaya. 2004. "Faktor-faktor yang Mempengaruhi Koefisien Respon Laba pada Perusahaan Bertumbuh dan Tidak Bertumbuh". Disampaikan pada Simposium Nasional Akuntansi VII. Denpasar. 2-3 Desember 2004.

Sugianto, Azmi, Z., \& Ramashar, W. (2020). Determinants of Budgetary Slack. E-Jurnal Ilmiah Akuntansi, 4(3), 262-270.

Susanti, Luh Gede. 2003. "Pengaruh Ukuran Perusahaan (Firm Size) Terhadap Kinerja Keuangan pada Perusahaan Food \& Beverage yang Terdaftar di PT. Bursa Efek Jakarta". Skripsi Sarjana Jurusan Manajemen, Fakultas Ekonomi Universitas Udayana

Tan, Chinhwee \& Robinson, T. R. (2014). Asian Financial Statetemennt Analysis Detecting Financial Irregularities. In Angewandte Chemie International Edition, 6(11), 951-952. Wiley. 
Wahyuni, windy S. (2013). TANGGUNG JAWAB AKUNTAN PUBLIK ATAS LAPORAN KEUANGAN YANG OVERSTATED DIPASAR MODAL. UNIVERSITAS SUMATERA UTARA.

Wedasuara Putra, I Made. 2007. "Pengaruh Cash Ratio, Leverage Management, Loan To Deposit Ratio dan Capital Adequacy Ratio Terhadap Profitabilitas Pada Bank-bank Yang Terdaftar Di Bursa Efek Jakarta Periode 2001-2005". Skripsi Sarjana Jurusan Manajemen Fakultas Ekonomi Universitas Udayana.

\section{Sumber website:}

https://journal.ubaya.ac.id/index.php/jimus/article/view/3619, 16 Juli 2021

http://journal.ubaya.ac.id/index.php/jim us/article/view/3619/2745, 16 Juli 2021

https://bisnis.tempo.co/read/33339/bapepam-kasus-kimia-farma-merupakan-tindak-pidana, diakses juli 2021.

Warta Ekonomi. 2017. Ketika Skandal Fraud Akuntansi Menerpa British Telecom dan PwC. http://wartaekonomi.co.id/read145257/ketika-skandal-fraudakuntansi-menerpa-british-telecomdan-pwc.html 